\section{Implementasi Kebijakan Pengelolaan BUMDes Pada Masa Pandemi Di Desa Protomulyo Kaliwungu Selatan Kabupaten Kendal}

\author{
Maulida Putri Rahmawati ${ }^{\text {1) }}$, Suwarji ${ }^{2 \text { ) }}$ \\ ${ }^{1}$ Program Studi Ilmu Pemerintahan, \\ Universitas Selamat Sri. \\ ${ }^{2}$ Program Studi Ilmu Pemerintahan, \\ Universitas Selamat Sri. \\ * Korespondensi Penulis. E-mail: \\ maulidaputri2791@gmail.com
}

\begin{abstract}
Abstrak
Tulisan ini bertujuan untuk menganalisis dan mendeskripsikan bagaimana implementasi kebijakan pengelolaan BUMDes pada masa pandemi di Desa Protomulyo, Kaliwungu Selatan di Kabupaten Kendal. Penelitian ini menggunakan metode kualitatif deskriptif. Teknik menentukan informan menggunakan purposive sampling berdasarkan subjek yang mendominasi dan bersedia memberikan keterangan. Informan penelitian adalah perangkat Desa Protomulyo dan pengurus BUMDes melalui wawancara dan observasi. Analisis data menggunakan teori dari Miles \& Huberman. Hasil penelitian menunjukkan, pengelolaan BUMDes pada masa pandemi di Desa Protomulyo, Kaliwungu Selatan Kabupaten Kendal memiliki beberapa permasalahan dilihat dari Indikator Kooperatif dan Berkelanjutan. Pertama, kerja sama terhambat oleh pandemi, sehingga pendapatan mengalami penurunan. Kedua, BUMDes belum ada perbaikan karena pandemi sehingga tidak bisa berjalan optimal. Faktor yang mempengaruhi terdiri dari komunikasi, sumber daya, disposisi dan struktur birokrasi. Indikator komunikasi adalah indikator dominan yang menyebabkan masalah karena Desa Protomulyo tidak memiliki dana yang cukup untuk mengembangkan kebijakan BUMDes.
\end{abstract}

Kata kunci: Implementasi, Kebijakan, BUMDes

\section{Implementation of BUMDes Management Policy During Pandemic At Protomulyo Village South Kaliwungu, Kendal Regency}

\begin{abstract}
This paper aims to analyze and describe how the implementation of BUMDes management policy during pandemic at Protomulyo Village, South Kaliwungu, Kendal Regency. This study used descriptive qualitative method. Determining informants methods are using purposive sampling based on the subject who dominate and willing to give an information. The informants were staffs and member of BUMDes. by interview and observation. Data analysis uses theories from Miles \& Huberman. The results showed the implementation of BUMDes management policy during pandemic at Protomulyo Village, South Kaliwungu Kendal Regency have some problems viewed from Cooperation Indicators and Sustainable. First, cooperation was hampered by pandemic, so income has decrease. Second, BUMDes has no improvement yet because of pandemic so it can't run optimally. The affecting factors consist of communication, resources, disposition and structure bureaucracy. Communication is the most dominant who causing the problem because the budget is not enough to develop the BUMDes policy.
\end{abstract}

Keyword: Implementation, Policy, BUMDes 
JSPG: Journal of Social Politics and Governance Vol.3 No.1 Juni 2021

\section{A. PENDAHULUAN}

Pandemi adalah suatu wabah penyakit global. Menurut WHO pandemi dinyatakan ketika penyakit baru menyebar di seluruh dunia melampaui batas. Adapun Provinsi Jawa Tengah tempat dimana penelitian ini dilakukan

Tabel 1 Penyebaran Covid-19 Kabupaten/ Kota Jawa Tengah Per-Januari 2021

\begin{tabular}{|c|l|c|c|l|c|}
\hline No & Kab/ Kota & Kasus & No & \multicolumn{1}{|c|}{ Kab/ Kota } & Kasus \\
\hline $\mathbf{1}$ & Kota Semarang & 13.181 & $\mathbf{1 9}$ & Temanggung & 3.123 \\
\hline $\mathbf{2}$ & Magelang & 5.919 & $\mathbf{2 0}$ & Kota Surakarta & 3.002 \\
\hline $\mathbf{3}$ & Cilacap & 5.528 & $\mathbf{2 1}$ & Batang & 2.874 \\
\hline $\mathbf{4}$ & Kebumen & 5.488 & $\mathbf{2 2}$ & Purworejo & 2.637 \\
\hline $\mathbf{5}$ & Banyumas & 5.400 & $\mathbf{2 3}$ & Purbalingga & 2.515 \\
\hline $\mathbf{6}$ & Kendal & 5.315 & $\mathbf{2 4}$ & Boyolali & 2.513 \\
\hline $\mathbf{7}$ & Jepara & 4.809 & $\mathbf{2 5}$ & Pati & 2.258 \\
\hline $\mathbf{8}$ & Kudus & 4.791 & $\mathbf{2 6}$ & Wonogiri & 2.254 \\
\hline $\mathbf{9}$ & Wonosobo & 4.414 & $\mathbf{2 7}$ & Brebes & 2.025 \\
\hline $\mathbf{1 0}$ & Demak & 3.965 & $\mathbf{2 8}$ & Rembang & 1.953 \\
\hline $\mathbf{1 1}$ & Blora & 3.911 & $\mathbf{2 9}$ & Pekalongan & 1.944 \\
\hline $\mathbf{1 2}$ & Sragen & 3.859 & $\mathbf{3 0}$ & Banjarnegara & 1.830 \\
\hline $\mathbf{1 3}$ & Karanganyar & 3.858 & $\mathbf{3 1}$ & Kota Pekalongan & 1.674 \\
\hline $\mathbf{1 4}$ & Tegal & 3.564 & $\mathbf{3 2}$ & Kota Magelang & 1.591 \\
\hline $\mathbf{1 5}$ & Sekoharjo & 3.520 & $\mathbf{3 3}$ & Grobogan & 1.540 \\
\hline $\mathbf{1 6}$ & Klaten & 3.478 & $\mathbf{3 4}$ & Kota Tegal & 1.235 \\
\hline $\mathbf{1 7}$ & Pemalang & 3.334 & $\mathbf{3 5}$ & Kota Salatiga & 1.129 \\
\hline $\mathbf{1 8}$ & Semarang & 3.317 & & \multicolumn{1}{|c|}{ Jumlah } & 123.748 \\
\hline
\end{tabular}

Sumber : http://covid-19.go.id

Hal ini tentunya sangat berpengaruh terhadap wilayah Kabupaten Kendal dalam perkembangan wilayahnya, mulai dari sektor ekonomi, pembangunan, pelayanan dan implementasi kebijakan. Tidak hanya berdampak di pemerintah daerah Kabupaten Kendal saja, dampak ini juga sangat berpengaruh terhadap pemerintah yang ada dibawahnya, baik kecamatan, kelurahan, maupun desa dari segi lembaga-lembaga yang dikelola masing-masing pemerintahan tersebut. memiliki beberapa kabupaten/kota yang menjadi daerah persebaran. Salah satunya yaitu Kabupaten Kendal yang memiliki kasus terbanyak pada posisi ke enam sebagai daerah yang terkena kasus virus seperti yang dilihat pada tabel 1.1. 
JSPG: Journal of Social Politics and Governance Vol.3 No.1 Juni 2021

kekeluargaan serta gotong royong guna mewujudkan keadilan social (www.dpr.go.id/dokjdih).

Bebasnya Kendal dari desa tertinggal pun banyak didukung dengan perkembangan BUMDes yang kini menjadi 136 di seluruh kabupaten Kendal. Dikatakan kabupaten Kendal mewajibkan seluruh desa untuk membentuk BUMDes guna mengoptimalkan pemanfaatan dana desa dengan demikian selain pembangunan infrastruktur dana desa juga bisa dimanfaatkan untuk mengerakan perekonomian secara berkelajutan. Anggaran bantuan lainya disalurkan untuk peberdayaan ekonomi desa diantaranya melalui UMKM sesuai potensi dan kondisi desa (Junaidi, 2018).

Desa Protomulyo merupakan salah satu desa yang berada di Kecamatan Kaliwungu Selatan Kabupaten Kendal yang melaksanakan BUMDes dengan nama BUMDes Mulyo Mandiri. Sesuai amanat dari UUD No 6 tahun 2014 tentang Desa pada pasal 87 menyatakan bahwa BUMDes di bentuk atas dasar semangat kekeluargaan dan gotong royong dengan adanya potensi ekonomi, kelembagaan ekonomi, sumber daya alam, serta sumber daya manusia dalam rangka mensejahterakan masyarakat perdesaaan. Namun, pandemi covid-19 menjadi penghambat dalam pelaksaan pengelolaan BUMDes Mulyo Mandiri. Padahal BUMDes sebagai lembaga ekonomi desa yang legal memiliki peranan penting dalam meningkatkan usaha perekonomian masyarakat desa perlu didukung oleh pihak pemerintah, sebagai basis pengembangan industri kecil menengah kebawah ataupun UMKM yang diharapkan dapat melahirkan produk-produk unggulan lokal yang mampu menjadi citra positif dalam kompetensi pasar (Harmiati, 2013).

Seiring dengan permasalahan pandemi covid-19 yang belum berakhir mengakibatkan kendala dalam pelaksanaan pengelolaan BUMDes yang tidak bisa berjalan dengan maksimal. Dalam rangka mengetahui dan menganalisis permasalahan implementasi kebijakan pengelolaan BUMDes serta faktor apa saja yang mempengaruhi pengelolaan BUMDes pada masa pandemi maka peneliti tertarik menulis penelitian yang berjudul "Implementasi Kebijakan Pengelolaan BUMDes Pada Masa Pandemi di Desa Protomulyo Kecamatan Kaliwungu Selatan Kabupaten Kendal”.

Rumusan masalah yang diambil dalam melakukan penelitian ini yaitu bagaimana implementasi kebijakan pengelolaan badan usaha milik desa pada masa pandemi di desa protomulyo kecamatan kaliwungu selatan kabupaten Kendal. Kedua yaitu apa saja faktor-faktor yang mempengaruhi implementasi kebijakan tersebut. Kemudian tujuan dari penelitian ini adalah untuk menganalisis dan mendeskripsikan bagaimana implementasi kebijakan pengelolaan badan usaha milik desa pada masa pandemi di desa protomulyo kecamatan kaliwungu selatan kabupaten Kendal beserta faktor-faktor yang mempengaruhinya.

Adapun kegunaan penelitian secara teoretis yaitu penelitian ini diharapkan dapat memberikan kontribusi pemikiran bagi pengembang ilmu pengetahuan pada umumnya dan administrasi publik maupun ilmu pemerintahan. Terkhusus pada bidang kebijakan publik dalam hal implementasi kebijakan pengelolaan badan usaha milik desa pada masa pandemi di desa protomulyo kecamatan 
JSPG: Journal of Social Politics and Governance Vol.3 No.1 Juni 2021

kaliwungu selatan kabupaten Kendal serta bermanfaat bagi penelitianpenelitian ilmu administrasi publik selanjutnya. Begitu juga secara praktis, penelitian ini diharapkan dapat bermanfaat bagi masyarakat pada umumnya maupun bagi Pemerintah Daerah Kabupaten Kendal dalam konteks kebijakan pengelolaan badan usaha milik desa pada masa pandemi di desa protomulyo kecamatan kaliwungu selatan.

\section{B. TEORI (Literature Review)}

Kajian penelitian terdahulu tentang implementasi kebijakan pengelolaan BUMDes pada masa pandemi pernah dilakukan peneliti sebelumnya yang berjudul Optimalisasi Peran BUM Desa dalam Pengembangan Ekonomi Perdesaan di Masa Pandemi Covid-19. Hasil penelitian menunjukkan bahwa urgensi BUM Desa karena kontribusinya yang besar bagi desa, tetapi terdisrupsi oleh pandemi. Upaya optimalisasi peran BUM Desa di antaranya dengan mendorong BUM Desa sebagai penyedia bahan makanan pokok di desa, bekerjasama dengan berbagai pihak eksternal, pemberian insentif dan kredit modal kerja, dan dilakukannya pendidikan dan pelatihan SDM pengelola (Zakariya, 2020)

Kemudian penelitian lain terkait BUMDes yakni berjudul Strategi Bertahan Badan Usaha Milik Desa (BUMDes) dalam Pandemi COVID-19 pada Desa Cibodas Kecamatan Lembang Kabupaten Bandung Barat. Hasi dari penelitian ini menunjukan bahwa BUMDes Karya Mandiri tetap bisa bertahan di tengah pandemi COVID-19 melalui kearifan lokal dan digitalisasi usaha meskipun terjadi penurunan omzet usaha sampai dengan 33\% (Balqis dkk, 2020).
Penelitian lain yakni Implementasi Strategi Pengembangan Badan Usaha Milik Desa di Kabupaten Banyumas Provinsi Jawa Tengah. Hasil penelitian menunjukkan bahwa kebijakan dalam pelaksanaan strategi memiliki posisi yang sangat penting untuk mengimplementasikan pengelolaan BUMDes. Kemudian partisipasi masyarakat memegang peranan penting dalam implementasi strategi dalam memberikan sumber pemikiran dalam pengelolaan BUMDes (Denok dkk, 2019).

Adapun penelitian lain mengenai kebijakan BUMDes juga pernah dilakukan di Kabupaten Sukabumi dengan studi kasus Desa Cisande Kecamatan Cicantayan. Penelitian ini menjelaskan tentang Program Bumdes yang terkendala oleh sumber daya manusia yang dalam pelaksanaan program BUMDes secara kualitas sangat kurang, dari segi kualitas, sumber daya yang ada tidak faham teknologi sehingga masih dilakukan pembukuan secara manual sehingga pengelolaan adminitrasi belum berjalan dengan baik, serta kurangnya Sosialisasi program BUMDes baik sosialisasi pemerintahan daerah ke desa desa maupun sosialisasi pemerintah desa kepada masyarakat desa (Meigawati, 2018).

Berdasarkan uraian di atas, penelitian-penelitian yang sudah dilakukan oleh beberapa peneliti terdapat beberapa persamaan dan perbedaan dengan penelitian yang Peneliti lakukan. Persamaan dengan penelitian-penelitian tersebut yaitu penelitian ini melihat bagaimana sebuah implementasi pada pengelolaan BUMDes pada masa pandemi. Dimana pada penelitian ini akan melihat implementasi kebijakan pengelolaan BUMDes yang terkendala oleh pandemi 
JSPG: Journal of Social Politics and Governance Vol.3 No.1 Juni 2021

covid-19 di Desa Protomulyo Kecamatan Kaliwungu Selatan Kabupaten Kendal.

\section{METODE}

Kajian implementasi kebijakan pengelolaan BUMDes pada masa pandemi di Desa Protomulyo Kecamatan Kaliwungu Selatan Kabupaten Kendal dilakukan dengan menggunakan pendekatan deskriptif-kualitatif, yaitu suatu metode yang mengamati, menganalisis dan menggambarkan fenomena yang terjadi dalam implementasi kebijakan publik untuk kemudian dilakukan eksplorasi data, baik data primer maupun data sekunder. Data primer diperoleh melalui wawancara dengan cara tanya jawab secara langsung antara peneliti dengan subjek penelitian atau informan yakni kepala seksi pemerintahan dan staf perangkat desa protomulyo yang mengetahui tentang BUMDes. untuk mendapatkan informasi yang berkenaan dengan implementasi kebijakan pengelolaan badan usaha milik desa pada masa pandemi di desa protomulyo kecamatan kaliwungu selatan kabupaten Kendal. Data sekunder diperoleh dari beberapa sumber jurnal, buku, literature data materi yang menunjang. Adapun lokasi penelitian terletak di Desa Protomulyo Kecamatan Kaliwungu Selatan Kabupaten Kendal.

Penelitian ini menggunaan metode pengamatan atau observasi nonpartisipan. Observasi bias diartikan sebagai pengamatan dan pencatatan secara sistematis terhadap gejala yang nampak pada obyek penelitian (Nawawi, 2001). Kemudian setelah melakukan observasi, peneliti melakukan wawancara dengan mengajukan pertanyaan, dengan yang diwawancarai, yaitu pihak yang memberikan jawaban atas pertanyaan tersebut.

Setelah kedua tahapan tersebut dilakukan, tahap terakhir yakni melakukan dokumentasi. Dokumen adalah setiap bahan tertulis ataupun film lain dari rekaman yang tidak dipersiapkan karena adanya permintaan dari seorang penyelidik (Moleong, 2002). Dalam penelitian ini teknik dokumentasi berfungsi sebagai pelengkap data yang digunakan untuk memperoleh data berupa dokumen-dokumen yang berkaitan dengan BUMDes.

Setelah mendapatkan data, dilakukan analisis dengan menggunakan teori implementasi Edward III dengan idikator berupa komunikasi, sumber daya, disposisi dan struktur birokrasi. Lebih lanjut, dalam menganalisis pengelolaan BUMDes, peneliti menggunakan prinsipprinsip pengelolaan BUMDes yang diatur dalam buku panduan BUMDes yang dikeluarkan Departemen Pendidikan Nasional untuk mendeskripsikan implementasi kebijakan pengelolaan BUMDes pada masa pandemi di desa protomulyo kecamatan kaliwungu selatan kabupaten Kendal.

Kemudian alur kegiatan dalam menganalisis data, peneliti mengambil dari teori Miles \& Huberman yang terdiri dari tiga alur kegiatan yang terjadi secara bersamaan yaitu; reduksi data dengan cara dirangkum, dipilih hal-hal yang pokok menyangkut implementasi kebijakan pengelolaan BUMDes pada masa pandemi. Lalu melakukan penyajian data, kemudian menarik kesimpulan. 
JSPG: Journal of Social Politics and Governance Vol.3 No.1 Juni 2021

\section{HASIL DAN PEMBAHASAN}

\section{Implementasi kebijakan pengelolaan BUMDes di Desa Protomulyo}

Implementasi

kebijakan

pengelolaan BUMDes di Desa Protomulyo Kecamatan Kaliwungu Selatan Kabupaten Kendal dianalisis menggunakan prinsipprinsip pengelolaan BUMDes yang diatur dalam buku panduan BUMDes yang di keluarkan Departemen Pendidikan Nasional (2007:13). Prinsip-prinsip ini adalah pedoman bagi pengurus BUMDes dalam menjalankan BUMDes, sehingga tujuan BUMDes sebagai entitas usaha yang tidak hanya mengedepankan profit melainkan dapat meningkatkan manfaat pada kehidupan sosial ekonomi masyarakat desa. Terdapat 6 (enam) prinsip dalam mengelola BUMDes. Pertama, kooperatif, dimana semua komponen yang terlibat di dalam BUMDes harus mampu melakukan kerjasama yang baik demi pengembangan dan kelangsungan hidup usahanya. Berdasarkan hasil penelitian dijelaskan bahwa seluruh komponen pengurus BUMDes Mulyo Mandiri Desa Protomulyo sangat kooperatif dalam pengelolaan BUMDes. Namun dengan adanya pembatasan kegiatan masyarakat pada masa pandemi ini sangat berpengaruh terhadap omset BUMDES yang dampaknya dirasakan pada beratnya beban operasional BUMDes. Seperti yang dikemukakan oleh Kepala Seksi Bidang Pemerintahan Desa Protomulyo :

"Kami sangat kooperatif, mengingat BUMDes Mulyo Mandiri selama ini bergerak di bidang persewaan ruko di lingkungan Wisata Religi di makam kanjeng sunan Katong yang sangat bergantung pada kunjungan wisatawan pada objek wisata tersebut.
E-ISSN 2685-8096 || P-ISSN 2686-0279

Dengan adanya pembatasan kegiatan masyarakat dampaknya dirasakan pada beratnya beban operasional BUMDes namun kesulitan tersebut dapat ditangani dengan baik berkat kerjasama dengan Pemerintah desa. Pemerintah desa memberikan penyertaan modal guna meringankan beban operasional dari BUMDes selama masa Pandemi”. (16/3/21)

Hal ini didukung dengan pernyataan perangkat desa yang menjelaskan bagaimana mempertahankan kelangsungan BUMDes selama pandemi, sebagai berikut:

"Dengan adanya masa pandemi, menuntut semua bidang usaha untuk lebih kreatif. Untuk terus mempertahankan eksistensinya, BUMDes Mulyo Mandiri melakukan perluasan cakupan usaha, seperti yang sedang berjalan BUMDes menggandeng perusahaan-perusahaan swasta di wilayah Kaliwungu untuk turut membantu. Salah satunya dengan memberikan bekal keterampilan kepada warga desa yang membutuhkan. Dengan adanya pelatihan tersebut, diharapkan perusahaan-perusahaan mau untuk membagi produksinya kepada BUMDes." (17/3/21)

Berdasarkan wawancara di atas dapat disimpulkan bahwa dalam menjalankan kebijakan BUMDes pada masa pandemi, BUMDes Mulyo Mandiri terkendala dengan pembatasan kegiatan sosial sehingga membuat penurunan omset. Dengan penyertaan modal karena adanya kerjasama dengan perusahaan swasta dapat membantu berjalannya BUMDes, melalui ketrampilan kepada warga desa yang membutuhkan. 
JSPG: Journal of Social Politics and Governance Vol.3 No.1 Juni 2021

Pemberlakuan Pembatasan Kegiatan Masyarakat (PPKM) di Kabupaten Kendal sendiri dilakukan dalam rangka penanggulangan penyebaran Covid-19. Pemerintah Kabupaten Kendal meminta masyarakat agar bisa menahan diri untuk tidak mengadakan kegiatan sosial selama PPKM diterapkan. Kebijakan PPKM ini mengacu pada Perbup Kabupaten Kendal Nomor 67 tahun 2020. Sejalan dengan penelitian yang dilakukan oleh Rizki Zakariya dalam Jurnal Ekonomi Indonesia bahwa Covid-19 menimbulkan dampak negatif bagi penyediaan bahan makanan pokok di pedesaan, karena pembatasan keluar-masuk kendaraan atau orang yang mengangkut bahan pokok dari wilayah yang menetapkan PSBB. Hal itu menimbulkan penurunan permintaan hasil produksi pertanian perdesaan dari pasar, yang selanjutnya menimbulkan kerugian bagi petani serta menurunnya daya beli masyarakat desa. Oleh karena itu, perlu peran pemerintah dalam mengentaskan masalah penyediaan bahan makanan pokok di desa (Rizki Zakariya, 2020).

Kedua, partisipatif dimana semua komponen yang terlibat di dalam BUMDes harus bersedia secara sukarela atau diminta memberikan dukungan dan kontribusi yang dapat mendorong kemajuan usaha BUMDes. Dukungan yang memajukan usaha BUMDes selama pandemi yakni penyertaan modal dan karakteristik dari kemampuan pemimpin untuk mengembangkan BUMDes. Seperti yang disampaikan oleh perangkat Desa Protomulyo :

"Dukungan dalam bentuk penyertaan modal dan managerial, dalam hal ini managerial yang dimaksud adalah perubahan pimpinan selain karena memang habis masa tugas, tetapi juga
E-ISSN 2685-8096 || P-ISSN 2686-0279

pemerintah desa menginginkan pimpinan BUMDes yang lebih mampu untuk" $(17 / 3 / 21)$

Selain itu, juga diperkuat dengan pendapat kepala seksi pemerintahan sebagai berikut :

"Selama pandemi justru partisipasi dan dukungan terhadap BUMDes semakin tinggi guna menjaga eksistensi selama pandemic dan dapat bertahan dikemudian hari."(16/3/21)

Berdasarkan hasil wawancara di atas dapat disimpulkan bahwa pemerintah desa menginginkan dukungan dari pimpinan BUMDes yang lebih mampu memberikan kontribusi untuk mendorong kemajuan BUMDes sebagai upaya untuk mempertahankan eksistensi BUMDes selama pandemi. Untuk itu, penting bagi sebuah organisasi BUMDes selain habisnya masa tugas sebagai pemimpin, pemimpin yang berikutnya harus memiliki kemampuan managerial dalam pengelolaan BUMDes. Mengingat bahwa pandemic belum berkakhir maka dibutuhkan kepemimpinan yang memiliki kontribusi penuh terhadap kemajuan BUMDes Protomulyo.

Ketiga, emansipatif dimana komponen yang terlibat di dalam BUMDes harus diperlakukan sama tanpa memandang golongan, suku, dan agama. Hasil penelitian menunjukkan bahwa selama ini BUMDes Desa Protomulyo tidak memandang golongan, suku maupun agama. Siapa saja yang mampu, dipersilahkan untuk dapat bergabung dalam manajemen BUMDes. Dan saat melakukan pelayanan kepada masyarakat, BUMDes tidak memandang golongan masyarakat. Seperti yang disampaikan oleh perangkat desa protomulyo, sebagai berikut: 
JSPG: Journal of Social Politics and Governance Vol.3 No.1 Juni 2021

"Tidak, tidak ada mebeda-bedakan baik suku, agama, golongan. Semua yang ingin masuk dalam kegiatan BUMDes kami persilahkan." $(17 / 3 / 21)$

Hal ini juga diperkuat oleh pernyataan lain oleh perangkat desa, seperti :

"Kalau ingin membantu BUMDes kami senang sekali, terbuka intinya. Apalagi ini masa pandemi, kalau ada yang ikut membantu justru kamu malah senang. Tidak ada pembedaan." (17/3/21)

Berdasarkan wawancara di atas dapat disimpulkan bahwa pada aspek emansipasif, lembaga BUMDes Mulyo Mandiri memiliki tingkat emansipasif yang baik. Hal ini dapat dilihat bahwa seluruh golongan masyarakat yang ingin berpartisipasi dipersilahkan untuk membantu kegiatan BUMDes. Apalagi pada masa pandemi ini BUMDes membutuhkan peran serta masyarakat dalam mempertahankan eksistensinya.

Keempat, transparan dimana hasil penelitian menunjukkan bahwa masyarakat umum memahami bahwa dengan adanya pandemi ini BUMDes mengalami keterbatasan kegiatan. Adapun sistem yang berada pada BUMDes Desa Protomulyo tidak mengalami perubahan dan hal ini diketahui oleh segenap lapisan masyarakat dengan mudah dan terbuka. Seperti yang disampaikan oleh perangkat desa sebagai berikut :

"Alhamdulillah masyarakat menyadari bahwa dalam masa Pandemi, BUMDes mengalami keterbatasan dalam melaksanakan kegiatanya.

Selain itu, beliau juga menegaskan bahwa:

"Tidak ada perubahan pola transparansi, baik sebelum maupun
E-ISSN 2685-8096 || P-ISSN 2686-0279

sesudah. seluruh informasi yang berkaitan dengan BUMDes Mulyo Mandiri di share dalam rapat bersama Pemerintah Desa." (17/3/21)

Dapat disimpulkan dengan apa yang telah dijelaskan oleh perangkat Desa Protomulyo bahwa BUMDes Desa Protomulyo berjalan dengan memenuhi aspek transparansi tanpa ada perubahan sistem selama pandemi. Sehingga dapat memenuhi anggapan bahwa kejujuran dan keterbukaan telah menjadi sistem nilai yang telah dimiliki BUMDEs Desa Protomulyo. Kemudian keberadaan BUMDes dengan prinsip transparan juga diharapkan mampu mewujudkan pengembangan dalam pengelolaannya.

Kelima, akuntabel dimana seluruh kegiatan usaha BUMDes harus dapat dipertanggung jawabkan secara teknis maupun administratif. Seperti yang disampaikan oleh Kepala Seksi Pemerintahan Desa Protomulyo :

"Pelaporan pertanggung jawaban masih dilakukan dengan tatap muka yang dilakukan satu tahun sekali." $(16 / 3 / 21)$

Hal ini juga didukung dengan pernyataan pengurus BUMDes, bahwa :

"Kami bertanggung jawab dengan apa yang telah kami laksanakan melalui pelaporan tahunan. Walau dana kami minim, tetap apapun hasilnya kami laporkan." (17/3/21)

Berdasarkan wawancara di atas dapat dikatakan bahwa seluruh kegiatan usaha dapat dipertanggung jawabkan secara teknis maupun administratif dengan menggunakan metode tatap muka sekali dalam setahun. Dengan demikian, pengelolaan BUMDes Desa Protomulyo 
JSPG: Journal of Social Politics and Governance Vol.3 No.1 Juni 2021

selama masa pandemi melaksanakan akuntabilitas dalam hal kegiatan pelaporan tahunan. Namun seharusnya, penyelenggaran pelaporan didukung dengan sistem pengawasan dan keseimbangan antara Pemerintah Desa dengan BUMDes Desa Protomulyo.

Keenam, sustainabel dimana pada aspek sustainabel kegiatan usaha BUMDes belum dapat dikembangkan dan dilestarikan oleh masyarakat karena terkendala oleh pandemi. Hal ini dikemukakan oleh Kepala Seksi Pemerintahan Desa Protomulyo, sebagai berikut :

"Untuk dapat terus berkelanjutan di masa pandemi, BUMDes Mulyo Mandiri masih mencoba untuk merintis kerjasama dengan perusahaanperusahaan swasta di wilayah Kaliwungu agar dapat membuka lahan usaha baru yang tidak bergantung pada kunjungan wisata Religi." (16/3/21)

Selain itu perangkat Desa Protomulyo juga mengatakan bahwa :

"Sementara ini kegiatan yang dikembangkan oleh BUMDes Desa Protomulyo hanya sewa ruko, dan pengelolaan parkir di kawasan Wisata Religi Makam Kanjeng Sinuwun Sunan Katong namun BUMDes sedang merintis kerjasama dengan perusahaan-perusahaan swasta di wilayah Kaliwungu." $(17 / 3 / 21)$

Berdasarkan hasil wawancara di atas bahwa BUMDes Desa Protomulyo terhalang pengembangannya karena pandemi. Namun tidak menyurutkan pengembangan lain untuk dapat mempertahankan eksistensi BUMDes untuk dapat berkelanjutan. Sehingga hal ini memberikan optimisme BUMDes di Desa Protomulyo.

$$
\text { Mengingat bahwa dalam }
$$

Permendesa Nomor 4 Tahun 2015 pendirian BUMDes dimaksudkan sebagai upaya menampung seluruh kegiatan ekonomi di bidang ekonomi dan pelayanan umum yang dikelola oleh desa. BUMDes didirikan dengan tujuan Meningkatkan pelayanan kepada masyarakat agar usahanya dapat berkembang, sehingga walaupun pada masa pandemi BUMDes harus tetap dikembangkan dalam rangka mengembangkan perekonomian yang berkelanjutan.

Berdasarkan analisis enam prinsip-prinsip pengelolaan BUMDes yang telah dideskripsikan. Peneliti dapat menyimpulkan beberapa hal yang dapat digaris bawahi sebagai berikut (1) BUMDes Mulyo Mandiri pada Desa Protomulyo selama masa pandemi tetap mempertahankan eksistensinya dengan melakukan cakupan perluasan usaha yang menutut kreatifitas walaupun mengalami penurunan omset. (2) Pemerintah Desa menginginkan perubahan kepemimpinan saat masa habis jabatan dengan harapan memiliki pemimpin yang dapat memberikan kontribusi dan mendorong kemajuan usaha BUMDes. (3) BUMDes Mulyo Mandiri di Desa Protomulyo mendapatkan dukungan dari masyarakat selama masa pandemi dalam bentuk partisipasi dan optimisme masyarakat dengan ikut mengembangkan usahausaha dari kegiatan BUMDes. 
JSPG: Journal of Social Politics and Governance Vol.3 No.1 Juni 2021

\section{Faktor Yang Mempengaruhi Pengelolaan BUMDes Desa Protomulyo}

Pertama, hasil penelitian menunjukkan bahwa komunikasi selama masa pandemi dilakukan sangat intens baik melalui online maupun tatap muka dengan menerapkan protokol kesehatan. Seperti pernyataan pengurus BUMDes berikut ini:

"Kaitannya dengan komunikasi, kami selalu memaksimalkan komunikasi ditengah pandemi ini, karena jika tidak ada komunikasi yang baik kami justru tidak berkembang. Padahal kami inginnya tetap eksis. Kalaupun ada perubahan kebijakan dilakukan rapat dan meminta pertimbangan terlebih dahulu kepada pemerintah desa." (17/3/21)

Hal ini juga dipertegas dengan pernyataan perangkat desa :

"Kita buat mudah saja komunikasinya. Bisa lewat video call, zoom atau melalui whatsap. Apalagi pengurus BUMDes yang baru ini interaktif." (17/3/21)

Selain itu, terkait evaluasi, BUMDes Mulyo Mandiri tetap melalukan evaluasi pengelolaan tetap melakukan evaluasi pengelolaan dana saat masa pandemi covid, namun tidak banyak dana yang dimiliki karena dana untuk BUMDes lebih banyak di alokasikan untuk penanganan Covid-19. Seperti yang diungkapkan oleh sekretaris BUMDes Mulyo Mandiri, sebagai berikut :

"Kami tidak banyak dana yang dimiliki karena lebih banyak di alokasikan untuk penanganan Covid19." $(17 / 3 / 21)$
Berdasarkan wawancara di atas dapat disimpulkan bahwa pengurus BUMDes yang baru sangat interaktif untuk dapat menggali potensi yang dapat dilakukan oleh BUMDes. Selain itu kebijakan BUMDes terlihat konsisten, apabila ada perubahan maka BUMDes Muyo Mandiri melakukan rapat dan meminta pertimbangan terlebih dahulu kepada pemerintah desa. Terkait dengan evaluasi, desa protomulyo tetap melakukan evaluasi pengelolaan dana saat masa pandemi covid, namun tidak banyak dana yang dimiliki karena dana untuk BUMDes lebih banyak di alokasikan untuk penanganan Covid-19.

Kedua, kondisi sumber daya manusia dalam pelaksanaan BUMDes di Desa Protomulyo adalah sumber daya manusia yang sifatnya relawan. Selain itu hasil penelitian menunjukkan bahwa sumber daya pada Desa Protomulyo sangat memadai. Seperti yang diungkapkan oleh Kepala Seksi Pemerintahan Desa Protomulyo, sebagai berikut :

"Kalau sumberdaya alhamdulilah punya struktur pengurus yang bakcgorund pendidikan nya bagus, bahkan ketua dan wakilnya saja S2." $(17 / 3 / 21)$

Adapun cara pelaksanaan kebijakan sesuai dengan AD/ART dengan sarana prasarana yang cukup memadai. Hal ini diungkapkan oleh pengurus BUMDes Mulyo Mandiri, sebagai berikut :

"Kegiatan kami pelaksanaan nya sesuai dengan AD/ART yang ada. Tapi karena pandemi ini dananya menjadi berkurang" (17/3/21)

Berdasarkan hasil wawancara di atas dapat disimpulkan bahwa pengurus 
JSPG: Journal of Social Politics and Governance Vol.3 No.1 Juni 2021

BUMDes Mulyo Mandiri memiliki sumber daya pengurus yang memadai. Sumber daya yang ada juga memiliki bidang keahlian yang sangat kompeten. Selain itu, kegiatan yang dilakukan pengurus dilaksanakan sesuai dengan anggaran rumah tangga BUMDes Mulyo Mandiri, namun dana yang dimiliki tidak banyak karena pandemi. Hal ini selaras dengan hasil penelitian yang dilakukan oleh Monika Balqis, yang menyatakan bahwa keberhasilan BUMDes sangat ditentukan oleh strategi yang diambil oleh sumber daya pengelola atau pengurus BUMDes. Dengan adanya sumber daya yang kompeten pada Desa Protomulyo, diharapkan mampu memberikan kontribusi yang dapat memberikan kesuksesan BUMDes.

Ketiga, hasil penelitian menunjukkan bahwa Pengurus BUMDes di pilih dan di angkat oleh Kepala Desa, seperti yang disampaikan oleh pengurus BUMDes Mulyo Mandiri :

"Pemilihan pengurus dipilih dan diangkat langsung oleh Kepala Desa dan disetujui oleh Badan Permusyawaratan Desa." (17/3/21)

Adaapun pengurus juga menerima insentif gaji seperti yang disampaikan oleh pengurus BUMDes, berikut ini:

"Ada insentif dari BUMDes." $(17 / 3 / 21)$

Berdasarkan wawancara di atas dapat disimpulkan bahwa pemilihan pengurus BUMDes melalui mekanisme Musyawarah Desa atas persetujuan BPD (Badan Permusyawaratan Desa) dengan tambahan insentif gaji. Sehingga sejauh ini pengurus BUMDes memiliki komitmen yang baik dalam pelaksanaan BUMDes. Dan juga kegiatan BUMDes Mulyo Mandiri dapat dijalankan dengan baik sesuai dengan program BUMDes.

Keempat, struktur organisasi yang bertugas mengimplementasikan kebijakan memiliki pengaruh yang significan terhadap implementasi kebijakan. Salah satu dari aspek struktur yang penting dari setiap organisasi adalah adanya prosedur operasi yang standard (standard operating procedures atau SOP). SOP yang digunakan oleh BUMDes Mulyo Mandiri mengacu pada UUD No 6 tahun 2014 tentang Desa. Seperti yang diungkapkan oleh pengurus BUMDes Mulyo Mandiri, berikut ini :

"Pedoman kita ya Undang-Undang No. 6 Tahun 2014 tentang Desa. Juga beberapa hal yang menjadi prinsipprinsip pengelolaan BUMDes sudah ada secara terpusat. Sehingga kami hanya melaksanakan saja." (17/3/21)

Beliau juga menambahkan berkaitan dengan struktur pengurus BUMDes Mulyo Mandiri, bahwa :

"Pengurus BUMDes Mulyo Mandiri disini hanya ada empat orang, yaitu Ketua, Wakil, Sekretaris dan Bendahara. Kerjasamanya dengan pemerintah Desa Protomulyo, pihak swasta dan masyarakat desa." $(17 / 3 / 21)$

Berdasarkan wawancara di atas dapat disimpulkan bahwa secara struktur organisasi BUMDes Mulyo Mandiri memiliki pengurus yang terdiri dari ketua, wakil, sekretaris dan bendahara. Selain itu, pedoman yang digunakan dalam pelaksanaan BUMDes mengacu pada UUD No. 6 Tahun 2014 tentang Desa. Sehingga regulasi nya terpusat sesuai dengan aturan pemerintah. 
JSPG: Journal of Social Politics and Governance Vol.3 No.1 Juni 2021

\section{E. SIMPULAN DAN SARAN Kesimpulan}

Implementasi

kebijakan pengelolaan BUMDes di Desa Protomulyo berjalan dengan menggunakan enam prinsip-prinsip pengelolaan BUMDes dengan melakukan kerjasama yang baik demi pengembangan BUMDes, namun terkendala dengan pembatasan kegiatan sosial sehingga membuat penurunan omset dari BUMDes. Kemudian dukungan penyertaan modal dari pemerintah desa protomulyo dianggap penting dalam kondisi pandemi ini untuk dapat mengembangkan BUMDes Mulyo Mandiri pada masa pandemi. Tidak hanya itu, tapi partisipasi masyarakat juga memiliki pengaruh dalam eksistensi BUMDes pada masa pandemic.

Dalam hal komunikasi, antar pengurus BUMDes menggali potensi BUMDes Mulyo Mandiri secara interaktif sehingga dapat mempertahankan eksistensi BUMDes. Namun demikian, pada masa pandemi BUMDes Mulyo Mandiri Desa Protomulyo tidak memiliki banyak karena lebih banyak di alokasikan untuk penanganan Covid-19. Hal ini tak mempersurut optimisme BUMDes Mulyo Mandiri untuk tetap mempertahankan kegiatan usahanya.

\section{Saran}

Pemerintah Desa Protomulyo harus lebih berperan aktif dalam pengembangan BUMDes Mulyo Mandiri untuk memaksimalkan pemasukan pendapatan BUMDes dalam menghadapi situasi pandemi. Maka dari itu perlu dilakukan pengkajian ulang dalam hal keberlanjutan BUMDes Mulyo Mandiri melalui peningkatan kegiatan BUMDes dengan menambah sarana dan prasarana untuk menunjang keberlanjutan pada masa pandemi. Selain itu, juga harus berani mengembangkan program yang memiliki potensi besar dengan menerapkan kreatifitas dan inovasi untuk meningkatkan pendapatan BUMDes Mulyo Mandiri.

\section{DAFTAR PUSTAKA}

Balqis Pratiwi, Monika, dkk. (2020). "Strategi Bertahan Badan Usaha Milik Desa (BUMDes) dalam Pandemi COVID-19 pada Desa Cibodas Kecamatan Lembang Kabupaten Bandung Barat" dalam Prosiding The 11th Industrial Research Workshop and National Seminar.

Departemen Pendidikan Nasional Pusat Kajian Dinamika Sistem Pembangunan. (2007). Buku Panduan Pendirian dan Pengelolaan Badan Usaha Milik Desa (BUMDes). Jakarta: Fakultas Ekonomi Universitas Brawijaya

Dine Meigawati. (2018). "Implementasi Program Bumdes di Kabupaten Sukabumi (Studi Kasus Desa Cisande Kecamatan Cicantayan)" dalam Jurnal Proceeding Konferensi Nasional Ilmu Administrasi.

Harmiati., Zulhakim, Abdul Aziz. (2013). Eksistensi Badan Usaha Milik Desa (Bumdes) Dalam Mengembangkan Usaha Dan Ekonomi Masyarakat Desa Yang Berdaya Saing Di Era Masyarakat Ekonomi Asean

Kurniasih, Denok dan Paulus Israwan Setyoko. (2019). "Implementasi Stratagi Pengembangan Badan Usaha Milik Desa di Kabupaten Banyumas Provinsi Jawa Tengah" dalam Jurnal Ilmiah Wahana Bhakti Praja, Vol. 9, No. 2. 
Vol.3 No.1 Juni 2021

Moleong, Lexy. (2002). Metodologi Penelitian Kualitatif. Bandung: PT. remaja Rosdakarya.

Muhammad Adib Junaidi. (2018). “Peran Badan Usaha Milik Desa (BUMDes) Dalam Penguatan Ekonomi Di Desa Kedung Turi Kecamatan Taman Kabupaten Sidoarjo" dalam Jurnal Ilmu Administrasi Negara, Jilid 5 No. 4.

Permendesa PDTT Nomor 4 Tahun 2015 tentang Pendirian, Pengurusan, dan Pengelolaan, dan pembubaran Badan Usaha Milik Desa. Diakses pada 10 Juni 2021, dari http://jdih.kemendesa.go.id

Peta Sebaran COVID-19. (2021). Penyebaran Covid-19 Kabupaten/ Kota Jawa Tengah. Diakses pada 21 Januari 2021, dari https://covid-19.go.id.

Subarsono, AG. (2005). Analisis Kebijakan Publik. Yogyakarta: Pustaka Pelajar

Sugiyono. (2013). Metodologi Penelitian Kuantitatif, Kualitatif Dan R\&D. Bandung: ALFABETA

Undang undang Nomor 6 tahun 2014 tentang Desa. Diakses pada 20 Januari 2021, dari www.dpr.go.id/dokjdih

Zakariya, Rizki. (2020). "Optimalisasi Peran BUM Desa dalam Pengembangan Ekonomi Perdesaan di Masa Pandemi Covid19" dalam Jurnal Ekonomi Indonesia Volume 9 Number 3. 